\title{
VENEREAL DISEASES FROM THE EPIDEMIOLOGICAL POINT OF VIEW
}

\section{Discussion}

Colonel Harrison said he found it difficult to say anything by way of discussion on the President's address because it left him dumb with admiration, and he felt that, if he were to say much, he would soon be floundering. Dr. Coutts had raised the old controversial question of the date of introduction of syphilis into Europe. He (Col. Harrison) had always inclined strongly to the view that the disease had been introduced by sailors landing at Barcelona after the discovery of America in I493. Dr. Coutts had, however, produced some arguments which were difficult to answer, more especially that immigrants to a country contracting syphilis there always seemed to suffer from it in a far more virulent form than did the natives. Being always anxious to find a reconciliation between opposing arguments, it had occurred to him that possibly an explanation of this and of the violence of the European epidemic which commenced in I495 when Charles VIII. was besieging Naples, might lie in the multiplicity of strains of $S p$. pallida. There was support for this in animal experiments. For example, if a rabbit was inoculated with a given strain, such as the Truff, and the resulting disease was allowed to progress for ninety days or more before being eradicated, one could not produce a second chancre with the same strain. If however, another strain such as the Nichol was employed for the re-inoculation, a syphiloma developed. It might be, therefore, that a given strain on first introduction into a community unaccustomed to that strain, though accustomed to other strains, might at first have produced a disease which was fairly ulcerative in its characteristics. Dr. Coutts had mentioned the possibility of carriers not themselves showing any manifestation whatever of the disease. The same idea had been put forward by Kolle after finding that mice inoculated with syphilis could 


\section{THE EPIDEMIOLOGICAL POINT OF VIEW}

harbour $S p$. pallida in their brains without these showing any sign of reaction on the part of the tissues. He had also mentioned the suggestion by Levaditi that there might be a life-cycle of the organism of syphilis, the intermediate stage being in the form of granules. Possibly, however, Bergel's explanation of these might be the right one. Bergel had traced histologically the infection of the tissues after experimental inoculation in rabbits and had found that the spirochætes retained their spiral formation until the exudation of lymphocytes occurred. Then they began to break up into granules, and Bergel had suggested that the breaking up was due to a lipolytic ferment secreted and thrown out by the lymphocytes. He had also quoted the suggestion by Stokes that there might be highly resistant strains of $S p$. pallida. This might be, but they had always in this connection to remember the possibility that in intractable cases it might be that the tissues had lost the power of making use of the remedies. They had support for this in cases which had been reported at one time and another. He had been greatly impressed by a case reported by Hoffman and Armuzzi in which a woman who relapsed with secondary manifestations after a course of treatment had proved completely resistant to the ordinary methods of treatment until a Zittmann's sweating cure had been given. After this she had responded to treatment in the normal way. Of course, there was mercury in Zittmann's decoction, but he could not help thinking that it was the change in the tissues resulting from the Zittmann treatment which had been responsible for the change in respect of response to arsenobenzol and bismuth. Other cases to which he had often referred were those reported by Major Pettit, R.A.M.C. In these, patients who had been resistant to treatment, or after a temporary response had promptly relapsed, had been made tractable by the administration of small doses of thyroid gland. Respecting variations in the character of syphilis, he had been interested in a paper written by Kanner, who put forward the theory that after an introduction into a community six to ten generations elapsed before one began to see such neuro-syphilis as tabes or G.P.I., that these manifestations reached their peak in six to ten more generations and then began to decline.

Kanner pointed out that tabes and G.P.I. appeared 


\section{BRITISH JOURNAL OF VENEREAL DISEASES}

first in Europe in 1670, which was approximately six generations after it was supposed to have been introduced, and that it was now declining. He showed that neurosyphilis was now increasing in negroes, while in Red Indians it was practically absent. He believed that in Red Indians the incidence of G.P.I. had long ago reached its peak. He said also that in Japan syphilis was very rife in I900, but there was no G.P.I. there, while now it was nearly as common as in Europe. In this connection it certainly was interesting that in this country there was a sudden fall in the deaths from G.P.I., namely, from an average from about 2,200 a year to about 1,500 , and that this reduction had been more or less maintained. As a little side evidence from a lay source of the mutilating effect of syphilis in this country, he would like to mention the very amusing "Essay on Noses," by Addison (The Tatler, December 7 th, I7ro). It opened with reference to a burlesque on the poem by Fracastorius, to which Dr. Coutts had referred. He would not spoil Addison's story by quoting that point, but would refer to his amusing account of the repair of noses by one Talicotius. He said that Talicotius was the first "clap" doctor of whom he had read. Talicotius took out a patent for the repair and replacement of noses. His first operation was on a Portuguese gentleman, and the new nose was made from the skin over the gluteal region of a German porter. The operation was successful from a morphological point of view, but artistically it had the defect that being cut from a blond German it did not match well with the swarthy countenance of its new host, so that it looked like one of those statues which has unfortunately lost its nose and has been repaired with a piece of new marble.

Talicotius improved on this by collecting a number of porters of different complexions so that those who required new noses could select one of the right tint. An unfortunate peculiarity of these noses was that they retained their sympathy with their original parent, so that it might happen that a gentleman who had received a new nose might wake one morning to find it considerably swollen and inflamed. On investigation in such a case, he might find that the porter for some delinquency had been violently kicked the day before on his posterior. Addison referred to one Englishman whose mode of 


\section{THE EPIDEMIOLOGICAL POINT OF VIEW}

life was such that he lost five noses, so much so that there was not a porter to be found who would supply him with a new one. He was known as the Englishman with the five noses.

Addison concluded his delightful essay with a little admonition to the young men coming up fresh to town not to imitate the rakes about town who behaved as if there were a Talicotius round each corner.

Dr. S. HARDY KInGSTON wished to endorse all that Colonel Harrison had said, and to thank the President for his very lucid address. When, two months ago, he encountered the President in an hotel at Rome, he little thought that the next time he saw him it would be to listen to such a wonderful address. When he was in China he was much struck by the fact that when Europeans contracted syphilis from Chinese, they had the disease in a very severe form, much more virulent than the natives. Among Russians extra-genital syphilis was extremely common.

He thought those who were present to-night might apologise for those of their friends who had missed hearing this extraordinarily good address, and he hoped that on the next occasion that the President addressed the Society the attendance would be much larger. $\mathrm{He}$ also wished to thank Colonel Harrison for his remarks, as that gentleman always gave his hearers something to think about. Those of us who come from the country liked to listen to his words of wisdom uttered at the meetings, as in the provinces there were not the same opportunities of seeing and hearing things.

COLONEL BURKE said he would like to join with others in congratulating the President on his most interesting and thought-provoking address.

The question of the origin of syphilis in the Old World had an important bearing epidemiologically, because it made a difference of several centuries in considering the time-factor, and in any epidemiological matter the time-factor was of first importance. His own inclination was to believe syphilis originated in the New World, and that it was unknown in Europe until the sailors returning with Columbus brought it into Spain. One thing which i seemed to point to that more than anything else was that he was unaware of any record of a case of congenital syphilis having occurred in Europe prior to I493. The 


\section{BRITISH JOURNAL OF VENEREAL DISEASES}

number of pre-Columbian bones existing in Europe must be many thousands of tons, yet there was no evidence of a pre-Columbian bone showing any evidence of syphilis, whereas the number of pre-Columbian bones in Mexico, in which country syphilis was supposed to have originated, contained specimens showing the disease. Syphilis in Europe after I493 appeared to have acted as syphilis did in Uganda when it was a new disease in that country. In Pacific Islands, to which the sailors accompanying Captain Cook imported the disease, the same happened. One could trace the spread of syphilis from Europe to the various countries, such as Africa and China, to which the explorers, such as Prince Henry the Navigator, went. Possibly syphilis did exist in early times in the Far East, but that was not incompatible with it having been brought from the Far West to Europe for the first time in I493. At one time Behring Strait probably united Asia to the American Continent. He was inclined to think that the clinical acumen of the observers during the Greek and Roman period was so great that if syphilis had existed among those people it would have taken a definite place in the writings. However, prior to I495, there was apparently no disease which resembled syphilis. Sir Jonathan Hutchinson referred to syphilis as "The Great Imitator" ; certainly it had imitated many skin diseases. In the Bible mention was made of diseases which might be leprosy, psoriasis, etc., which have a superficial resemblance to syphilis. The great test was the occurrence or absence of congenital syphilis, and till after I493 this is not mentioned.

He was interested in what had been said about Russia. $\mathrm{He}$, the speaker, had had experience of that country in I9I I-before the Russian Revolution-and also after it namely, in I9I8-I9, and on both dates he was struck with the amount of congenital and innocent syphilis which existed, especially in the country villages, so that he was not surprised to learn that in some villages as many as 80 per cent. of the population were suffering from the disease.

The President referred to instances in which the disease was more severe in immigrants than in natives, and that was brought especially to the speaker's notice during his war service in the Far East, especially on the frontiers of Persia. When a British soldier acquired syphilis 


\section{THE EPIDEMIOLOGICAL POINT OF VIEW}

there it was usually of a much more virulent type than among the ordinary residents. He thought it was because most of our men there were suffering from malaria and from the strain of active service. This difference in severity was also noticed during the Peninsular War, where similar factors-with the exception of malariawere operating upon the soldier and not upon the native.

He thanked the President sincerely for his address; he was glad that he had come from the wilds of Salford to hear it.

Dr. Ethel Browning (St. Paul's) said she had a visit recently from the Government pathologist of Trinidad, who said that syphilis was very rife in that island, though in a very mild form. Practically the whole native population was suffering from it, but it never attacked the brain or spinal cord. The speaker suggested to him that it might be a different strain, but the pathologist replied that he thought not, but that the whole of the population at some time had suffered from some form of malaria.

MAJOR DAwson said he had just come from Jamaica, where it was the popular idea that a large number of the people were suffering at the present time from syphilis; but Dr. Wilson, senior medical officer there on the civil side, said he had arrived at the conclusion that the sickness was probably due to yaws, which was known to be a near cousin of syphilis. It was difficult to get sufficient information on the point, and, even if it were scientifically explored, it would be difficult to make out which was syphilis and which was yaws, especially as the causal parasites of each were closely allied to each other. It was a question whether they overlapped or whether the presence of one prevented the other from developing. After all, relatively speaking, the spirochæte was so new that even the exact name was not yet fixed, though, no doubt, the protozoologists would find out more. The whole matter bore a resemblance to the fight which took place over the trypanosomes. It was only twenty-three years since the spirochæte was found, therefore it could not be wondered at that information of exact nature was so meagre. The paper of the President to-night on the different clinical types gave much food for thought and reflection. It also indicated how much yet remained to be worked out. 


\section{BRITISH JOURNAL OF VENEREAL DISEASES}

Dr. Dorothy Logan desired to add her thanks for the President's paper. One question-not quite a scientific one-occurred to her while listening: Was it not likely that adverse climatic conditions, such as the immigrant was unused to, might help in rendering him more susceptible to a violent attack of syphilis or any other disease than was the native resident?

The PRESIDENT, in reply, thanked members for the flattering way in which they had received his attempt to consider Venereal Diseases from a somewhat different aspect to that usual at meetings of the Society.

$\mathrm{He}$ did not propose to argue the question of preColumbian versus post-Columbian syphilis, but he .would allude to one or two points arising in the course of the discussion.

Colonel Harrison had referred to general paralysis of the insane taking six to ten generations to reach its height, and then going down. That observation, and others, suggested that in syphilis, as in other diseases, there were epidemic wave-cycles, and that a remarkably mild type of disease might yet affect a large area. In a community suffering from a mild type of the disease, the introduction of a fresh strain of spirochæte might lead to a much more virulent form of the disease. It was an aspect of the question which provided a good deal of food for thought ; no real explanation was yet forthcoming. One could not think merely of the disease parasite and the remedy; the tissues of the person and the resultant of the meeting of the forces of the parasite and of the host together with the action of the remedy had also to be taken into consideration. It was conceivable that the introduction of some outside influence might change the reaction of the tissues of the body so that the remedy might have its effect.

With regard to arseno-benzol, the evidence available was against the idea that this drug killed the parasite; the drug probably affected the tissues of the body in some way so that they were able to deal with the parasite; if the drug could not do this effectually it was conceivable that the use of some other drug in addition might turn the balance and enable the tissues to do what was required of them in throwing off the disease.

He hoped he had not conveyed the idea that he thought syphilis was a mild disease when it first appeared in 


\section{THE EPIDEMIOLOGICAL POINT OF VIEW}

Europe in the fifteenth century. Shakespeare's writings showed that syphilis was a mutilating disease in his time, though then it did not appear to have been so fatal as in the early part of the sixteenth century; indeed, it was made rather a matter of jest. But according to some of the earlier writers in the sixteenth century, large numbers died of syphilis in London. One writer, however, said he did not think the bills of mortality of that date were accurate, as in poor quarters of the City it was called syphilis, while in more prosperous quarters it was registered as "consumption." He, Dr. Coutts, feared that even now the certification of deaths from syphilis was not as accurate as it might be.

With regard to adverse climatic conditions, that was another epidemiological consideration which appeared to affect all epidemic diseases. Environment entered into the question of all epidemic diseases, and one must look upon both syphilis and gonorrhœa as infectious diseases with an epidemiology, just in the same way as scarlet fever, diphtheria, and other ordinary infectious diseases. If so, it was to be expected that syphilis would come in great waves, and then all but disappear. Later, a change in environment might occur and a further wave be brought about. Hence a marked diminution at a particular period need not necessarily mean that the disease was being stamped out. 